Historic, Archive Document

Do not assume content reflects current scientific knowledge, policies, or practices. 



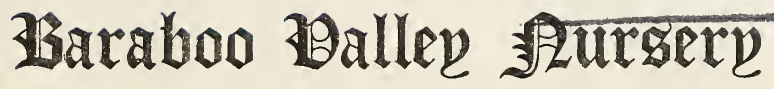

\author{
C. R. TUTTLE, Prop. \\ BARABOO, \\ WISCONSIN
}

\section{Small Fruit Plants for Spring 1929}

These small fruit plants are the best varieties, true to name, shipped

to you in the shortest possible time from our nursery post paid.

They will grow and please you. Send us your order early.

\section{STRAWBERRY PLANTS}

PROGRESSIVE EVERBEARING-Set this spring, will bear this fall, and then bear again early next summer. Best variety. $\$ 1.50$ per $100, \$ 10.00$ per 1000

SEN. DUNLAP-For all soils and parts of the country: a heavy bearer, dark berry. $\$ 1.35$ per $200, \$ 6.00$ per 1000

WARFIELD-A heavy bearer of dark berries, plant with the Dunlap. \$1.35 perg200, $\$ 6.00$ per 1000

GIBSON-An early berry, big yeilder, early. $\$ 1.35$ per200, $\$ 6.00$ per 1000

HOWARD-Also known as Premier, a large berry, a good one. $\$ 1.50$ per

$200, \$ 6.50$ per 1000

\section{Black Raspberries}

CUMBERLAND-The iargest and the best. $75 \mathrm{c}$ per doz. $\$ 4.50$ per 100

\section{Red Raspberries}

BARABOO-The new red raspberry. It's/Thornless, free from disease, never winter kills, extra early, heavy bearer, long season, get a start of these. \$5.00 per doz. $\$ 35.00$ per 100

ST. RECIS-Everbearidg, early, hardy $\$ 3.50$ per 100

LATHAM-Large, hardy, a good one. $\$ 5.00$ per 100

APPLE TREES-Large three-year trees; true to name. 50c each $\$ 20$ for 50 GRAPE VINES-Large two-year, vines, Moore's Early and Worden. $25 \mathrm{c}$ each

$\$ 2.50$ per doz.

Prices on Shade Treees, Shrubs, etc. on request. 
